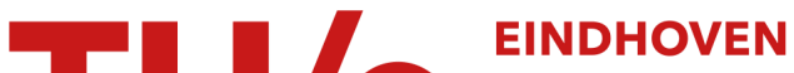 \\ UNIVERSITY OF \\ TECHNOLOGY
}

\section{Persuading older adults' to social and physical activities}

\section{Citation for published version (APA):}

Bekker, M. M., Romero Herrera, N. A., Sturm, J. A., Valk, de, L. C. T., \& Kruitwagen, S. (2010). Persuading older adults' to social and physical activities. Gerontechnology, 9(2), 194-194.

https://doi.org/10.4017/gt.2010.09.02.229.00

DOI:

10.4017/gt.2010.09.02.229.00

Document status and date:

Published: 01/01/2010

\section{Document Version:}

Publisher's PDF, also known as Version of Record (includes final page, issue and volume numbers)

\section{Please check the document version of this publication:}

- A submitted manuscript is the version of the article upon submission and before peer-review. There can be important differences between the submitted version and the official published version of record. People interested in the research are advised to contact the author for the final version of the publication, or visit the $\mathrm{DOI}$ to the publisher's website.

- The final author version and the galley proof are versions of the publication after peer review.

- The final published version features the final layout of the paper including the volume, issue and page numbers.

Link to publication

\section{General rights}

Copyright and moral rights for the publications made accessible in the public portal are retained by the authors and/or other copyright owners and it is a condition of accessing publications that users recognise and abide by the legal requirements associated with these rights.

- Users may download and print one copy of any publication from the public portal for the purpose of private study or research.

- You may not further distribute the material or use it for any profit-making activity or commercial gain

- You may freely distribute the URL identifying the publication in the public portal.

If the publication is distributed under the terms of Article 25fa of the Dutch Copyright Act, indicated by the "Taverne" license above, please follow below link for the End User Agreement:

www.tue.nl/taverne

Take down policy

If you believe that this document breaches copyright please contact us at:

openaccess@tue.nl

providing details and we will investigate your claim. 
M.M. BeKker, N.A. Romero, J. Sturm, L. de Valk, S. KRuitwagen. Persuading older adults to social and physical activities. Gerontechnology 2010;9(2):194; doi:10.4017/gt.2010.09.02.229.00 Purpose We report on a requirement analysis as part of the Independent Living Project ${ }^{1}$ to understand the role of social and physical activities in older people's life. The goal of the project is to design persuasive solutions that contribute to independent living. The project falls within the goals of prevention and engagement and the life domains of health, self-esteem and work/leisure in the area of gerontechnology ${ }^{2}$. Method Diaries, interviews and focus groups (12 older adults and 4 care givers) were conducted to collect qualitative data about social and physical activities in old people's daily life. Results \& Discussion We present two main findings. First, it is important to design for transitions of ageing because it can address two major challenges: maximising acceptance of technology and minimising stigmatisation. We found that various important changes in older adults' life influence the abilities and opportunities for social and physical activities. Products can support more fluent transitions in life, where users can develop alternative solutions that adapt to their needs over time. Therefore, solutions designed for transitions in life should satisfy a set of needs that cover use before, during and after these transitions. For example, when social contacts decrease because a partner or friend dies, or because people have to move to other locations, a solution that was already used to keep contact with their social network can also provide support finding and creating new contacts. Second, the relationship between social and physical activity can function as mutual motivators. Persuasive solutions for either physical ${ }^{3}$ or social activities ${ }^{4}$ exist. However, we have found few combined solutions. We have observed that the motivation for older adults to engage in certain activity, changes over time and varies depending on contextual factors (weather, location, quorum, etc.). For example, some people are interested in keeping fit; therefore, providing physical triggers might motivate them to engage in more social activities. Other people are interested in socializing; therefore providing social triggers might motivate them to do more physical activities. We identify two areas where technology could support both designing for transitions and using social and physical triggers as mutual motivators. They represent aspects in the life of an older adult related to self-awareness (personal activity monitoring) and social/group awareness (events/activities). Monitoring one's own activities is considered a physical motivator, creating awareness of their own capabilities and goals and helping them make informed decisions whether to do more activities or not. The latter is particularly important, as our observations showed that older adults need support for deciding when to take breaks. Similarly, sharing programmed and spontaneous activities is considered a social motivator, as it can create opportunities for social encounters in line with moment-tomoment needs and desires. The design for transitions approach requires modular and flexible solutions, allowing people to develop different uses over time. Secondly, to design using mutual motivators we integrate a playful persuasive component to evoking a fun experience.

\section{References}

1. http://www.idemployee.id.tue.nl/m.m.bekker/research.htm\#_Playful_Persuasion_for_1; retrieved January, 2010

2. Bouma H, Fozard JL, Bronswijk, JEMH van. Gerontechnology as a field of endeavour. Gerontechnology 2009;8(2):68-75; doi:10.4017/gt.2009.08.02.001.00

3. Hirsch T, Forlizzi J, Hyder E, Goetz J, Stroback J, Kurtz C. The ELDer Project: Social, Emotional, and Environmental Factors in the Design of Eldercare Technologies. In Proceedingsof the Conference on Universal Usability; 2000; pp 72-79; doi:10.1145/355460.355476

4. Mynatt ED, Rowan J, Craighill S, Jacobs A. Digital family portraits: supporting peace of mind for extended family members. In Proceeedings of the SIGCHI Conference on Human Factors in Computing Systems; 2001; pp 333-340; doi:10.1145/365024.365126

Keywords: independent living, persuasion, social and physical activity

Address: Eindhoven University of Technology, Faculty of Industrial Design, Netherlands;

E:m.m.bekker@tue.nl

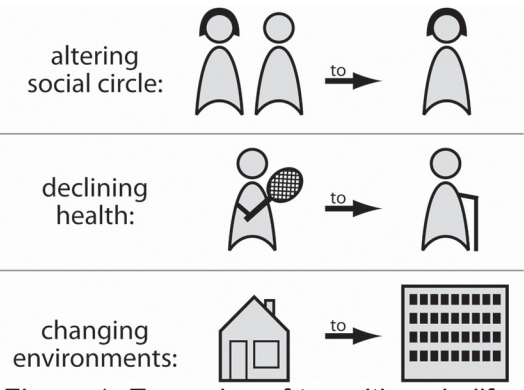

Figure 1. Examples of transitions in life 